\title{
Effect of turmeric on the physicochemical characteristics of 'Doenjang' during fermentation
}

\author{
Dong-Han Kim*, Suk Kim \\ Department of Food and Nutrition, Mokpo National University, Muan 58554, Korea \\ 강황이 된장의 발효에 미치는 영향 \\ 김동한*·김숙 \\ 목포대학교 식품영양학과
}

\begin{abstract}
In order to improve the quality of 'Doenjang', the effects of turmeric on its enzyme activity, microbial and physicochemical properties were investigated over a 12 week fermentation period. As the ratio of turmeric was increased, the numbers of yeast and anaerobic bacteria in the 'Doenjang' during fermentation decreased; its $\alpha$-amylase and acidic protease activity also decreased in the later stage of fermentation. The addition of turmeric gradually decreased the Hunter L-value, while it increased the $b$-value $(\mathbf{p}<0.05)$; however, the total color difference was low. The $\mathrm{pH}$ of the 'Doenjang' decreased slightly during fermentation, and increasing the turmeric concentration resulted in lower titratable acidity. The acid values $(\mathbf{p}<0.05)$ and oxidation-reduction potential of 'Doenjang' gradually decreased with the addition of turmeric during fermentation. The Aw value was high in the group with high concentrations of added turmeric. The reducing sugar content increased until 4- 6 weeks of fermentation, and was lowered with the addition of turmeric. The alcohol content was high in groups with high concentrations of added turmeric. As the ratio of turmeric was increased, the amount of amino-type nitrogen in the 'Doenjang' became high in the later stage of fermentation, while the amount of ammonia-type nitrogen was low.
\end{abstract}

Key words : 'Doenjang', turmeric, fermentation, physicochemical properties

서 론

우리나라 고유의 전통 발효식품인 된장은 곡류 위주의 식생활에서 부족하기 쉬운 단백질 함량이 높아 영양학적 으로 우수한 조미식품이다(Kim과 Kwon, 2014). 전통식 된장은 메주를 띄우는 과정에서 Bacillus sp. 등 세균과 곰팡이가 발효과정에 관여하나 개량식은 Aspergillus oryzae을 접종한 $k o j i$ 를 이용하기 때문에 맛과 생리활성 등 품질에서 차이가 있다(Lee 등, 2013). 최근에는 식생활 양식의 변화와 핵가족화, 편리성을 추구하는 소비자의 욕
구 때문에 된장의 소비도 공장에서 생산되는 제품의 수요 가 점점 증가되고 있다. 이에 따라 개량식 된장도 소비자의 기호에 맞게 전통식 방법을 혼용하는 절충식(Joo 등, 1992a)으로 하거나 녹차(Jung과 Roh, 2004)나 겨자, 키토산 등(Lim과 Song, 2010) 기능성 소재를 첨가하여 생리활성을 향상시키려는 연구가 활발히 진행되고 있다. 된장은 담금 시 $k o j i$ 의 종류(Joo 등, 1992b)와 고추씨 $(\mathrm{Ku}, 2009)$, 표고버 섯(Choi 등, 2006), 염생식물(Choi 등, 2018)의 첨가 등에 따라 품질 차이가 있으며, 소금의 종류와 농도(Kim, 2000) 에 따라서도 발효가 달라진다. 또한, 전통식 된장은 Bacillus

*Corresponding author. E-mail : dhankim@mokpo.ac.kr, Phone : +82-61-450-2524, Fax : +82-61-450-2529

Received 14 August 2019; Revised 18 September 2019; Accepted 19 September 2019.

Copyright (c) The Korean Society of Food Preservation.

This is an Open Access article distributed under the terms of the Creative Commons Attribution Non-Commercial License (http://creativecommons.org/licenses/by-nc/4.0) which permits unrestricted non-commercial use, distribution, and reproduction in any medium, provided the original work is properly cited. 
sp.가 발효에 관여 하기(Park 등, 2000) 때문에, 된장 제조시 국균 koji의 일부를 Bacillus속과 Monascus속 koji를 혼합 (Kim과 Rhyu, 2000)하거나 Rhizopus oryzae koji(Eum 등, 2003)로 대체하기도 하였다. 한편, 소금은 된장의 쓴맛에 도 관여하고(Okada 등, 1997), 과잉섭취가 각종 성인병의 원인이 되기도 한다. 따라서 된장의 제조도 소금의 농도를 $14 \%$ 이하로 저식염화(Mok 등, 2005; Lee와 Mok, 2010)하 는 것이 바람직하나 식염 농도가 낮아지면 발효. 숙성 과정에서 이상발효에 의한 품질 저하의 원인이 된다. 그러 나 된장 담금시 항균활성이 있는 알코올(Cha 등, 2017)이 나 마늘(Kang 등, 2014), 발효옻(Choi 등, 2015) 등 부원료를 이용하면 발효 중에 미생물의 생육을 효과적으로 조절할 수 있어 저식염 된장의 제조가 가능하다. 또한, 된장은 변색이 품질 저하의 주요 요인이 되기 때문에 발효 중에 유기산과 인산염 등 갈변억제제(Kim, 1996; Kwak과 Lim, 2003)를 첨가하거나 저장 중에 가열살균 처리(Kim 등, 1999)를 한다. 한편, 강황은 생강과에 속하는 다년생의 숙 근성 뿌리로 기능성 때문에 생약으로 사용되는 약용식물 (Park 등, 2007)이며 카레 등에 향신료로 이용되고 있다. 또한, 황색색소인 curcumin과 정유성분으로 tumerone과 dehydrotumerone을 함유하고 있어 이들에 의한 항균활성 과 항산화활성이 보고(Lee 등, 1997; Choi, 2009) 되었고, 고추장 발효에서도 강황의 항균활성과 변색방지 효과가 검토(Kim, 2013)된 바 있다.

이에 본 연구에서는 된장 발효·숙성에서 문제가 되는 변색방지와 저식염 된장 제조시 항균활성을 목적으로 강 황의 농도를 달리하여 첨가하고, 강황이 저식염 된장의 발효에 미치는 영향을 비교 검토하였다.

\section{재료 및 방법}

재료

된장 제조에 사용한 대두는 2016년산 백태품종을 농협
하나로 마트에서 구입하였으며, 소맥분 $k o j i$ 는 토박이순창 식품(Tobagi Soonchangfoods Co., Ltd., Soonchang, Korea) 에서 밀가루로 제조한 $k o j i$ 를 이용하였다. 식염은 꽃소금 ( $\mathrm{NaCl} 88 \%$, Youngjin Salt, Co., Ltd., Seoul, Korea), 알코올 은 무수알코올( $99.8 \%$, Baker, Deventer, Netherlands), 강황 은 분말(강황 $100 \%$, Gold Turmeric Co., Jindo, Korea)을 사용하였다.

\section{된장의 제조}

된장 제조시 대두는 24시간 침지시켜 물빼기를 한 후 $1.2 \mathrm{~kg} / \mathrm{cm}^{2}$ 압력으로 1 시간 증자한 후 chopper로 마쇄하여 소맥분 $k o j i$ 와 혼합하였다. 된장 담금은 Table 1 과 같이 강황을 $0.5 \%, 1 \%, 2 \%, 3 \%$ 되게 농도를 달리하여 첨가하고, 소맥분 $k o j i ~ 17 \%$ 첨가구를 대조구로 하여 소맥분 $k o j i$ 를 같은 비율로 줄이면서 혼합하고 $20^{\circ} \mathrm{C}$ 에서 12 주간 발효시 켰다.

\section{일반성분}

된장의 $\mathrm{pH}$ 는 $\mathrm{pH}$ meter(Orion 520A+, Beverly, MA, USA) 로 직접 측정하였고, 적정산도는 $0.1 \mathrm{~N} \mathrm{NaOH}$ 를 이용하여 $\mathrm{pH} 8.3$ 까지 적정하여 측정하였다. 일반성분은 기준미증분 석법(Institute of Miso Technologistts, 1968)에 준하여 환원 당은 Somogyi변법, 알코올은 산화법, 아미노산성 질소는 Formol적정법, 암모니아성 질소는 Folin법으로 정량하였 다. 산가는 식품공전에 준하여(Park 등, 2000) 된장 $2.5 \mathrm{~g}$ 에 ether-ethanol혼합액(1:2) $100 \mathrm{~mL}$ 를 혼합하여 자석교반기 로 10 분간 용출시킨 후 phenolphthalein을 지시약으로 하여 $0.1 \mathrm{~N}$ ethanol성 $\mathrm{KOH}$ 용액으로 적정하여 그 소비량으로 계산하였다.

\section{수분활성도와 색도, 산화환원전위}

수분활성도(Aw)는 전보(Cha 등, 2017)와 같이 Novasina LabSwift-Aw(CH-8353, Novasinar AG, Lachen, Switzerland)

Table 1. Mixing ratio of raw materials for preparation of 'Doenjang'

(Unit: \%)

\begin{tabular}{|c|c|c|c|c|c|c|}
\hline \multirow{2}{*}{$\begin{array}{c}\text { 'Doenjang' } \\
\text { with turmeric') }\end{array}$} & \multicolumn{6}{|c|}{ Raw material } \\
\hline & Soybean & Wheat koji & Turmeric & Ethanol & $\mathrm{NaCl}$ & Water \\
\hline Control & 27.0 & 17.0 & 0 & 2.0 & 9.5 & 44.5 \\
\hline $\mathrm{T}-0.5$ & 27.0 & 16.5 & 0.5 & 2.0 & 9.5 & 44.5 \\
\hline $\mathrm{T}-1$ & 27.0 & 16.0 & 1.0 & 2.0 & 9.5 & 44.5 \\
\hline $\mathrm{T}-2$ & 27.0 & 15.0 & 2.0 & 2.0 & 9.5 & 44.5 \\
\hline $\mathrm{T}-3$ & 27.0 & 14.0 & 3.0 & 2.0 & 9.5 & 44.5 \\
\hline
\end{tabular}

\footnotetext{
${ }^{1)}$ Doenjang added with different concentrations of turmeric.
} 
로, 색도는 색차계(Chromameter CR-200, Minolta, Osaka, Japan)로 측정하여 Hunter scale에 의해 L(lightness), a (redness), $\mathrm{b}$ (yellowness)값과 $\Delta \mathrm{E}=\left[\left(\mathrm{L}_{0}-\mathrm{L}_{1}\right)^{2}+\left(\mathrm{a}_{0}-\mathrm{a}_{1}\right)^{2}+\left(\mathrm{b}_{0}\right.\right.$ $\left.\left.-b_{1}\right)^{2}\right]^{1 / 2}$ 값으로 표시하였다. 산화환원전위(oxidationreduction potential, ORP)는 된장을 2 배 희석한 후 ORPmeter(Onion 525A + , Beverly, MA, USA)를 이용하여 직접 측정하였다.

\section{생균수와 효소활성도}

된장의 호기성세균은 tryptic soy agar(Thomas 등, 1981), 통성혐기성세균은 APT agar(Difco Laboratories, 1984)를 사용하여 평판도말 한 후 $1.5 \%$ agar를 덮어 중층 배양하였 고, 효모는 rose bengal agar(Martin, 1950) 배지를 사용하여 평판도말법으로 $28^{\circ} \mathrm{C}$ 에서 1-3일간 배양한 후 계수하였다 (Lee와 Kim, 2012). 효소활성도는 전분액화력은 Fuwa의 방법(Fuwa, 1954)에 준하여 blue value변법으로 측정한 후 활성도는 10 분 반응 전후의 흡광도 차이로 표시하였고, 전분당화력은 된장 $1 \mathrm{~g}$ 에서 1 시간 반응 후 생성되는 환원 당을 DNS법(Miller, 1959)으로 정량하여 glucose 양 $(\mu \mathrm{M})$ 으 로 표시하였다. 단백질 분해력은 Anson의 방법(Anson, 1938)에 준하여 $\mathrm{pH} 3.0,6.0$ (편의상 산성, 중성 protease로 함)으로 구별하여 측정하여 된장 $1 \mathrm{~g}$ 에서 30 분에 생성하는 $1 \mu \mathrm{M}$ 의 tyrosine 양을 1 unit로 나타냈다. 모든 측정값은
3회 반복 측정하였으며, SPSS/PC package 23.0(SPSS Inc., Chicago, IL, USA)을 이용하여 분산분석을 하고, Duncan's multiple range test에 의해 $\mathrm{p}<0.05$ 수준에서 통계 처리하였다.

\section{결과 및 고찰}

\section{미생물상}

된장 발효과정 중 미생물상의 변화는 Table 2 와 같다. 된장의 효모수는 발효 4주까지는 증가되었으나, 그 이후에 는 강황을 첨가하지 않은 대조구를 제외하고는 감소하는 경향이었고, 강황의 첨가비율이 증가할수록 유의적인 차 이는 없으나, 발효 후기의 효모수는 적었다. 효모는 된장의 발효과정에서 당으로부터 알코올을 생산하여 유기산과 ester화 되어 향기성분을 생성하기도 하지만, 지나치면 이 상발효에 의한 가스 생성으로 된장이 괴어오르는 원인이 되기도 한다(Mok 등, 2005). 이러한 관점에서 볼 때 강황 첨가로 저식염 된장의 발효 중 이상발효의 원인이 되는 효모의 증식을 효율적으로 조절할 수 있을 것으로 사료되 었다. 그러나 저식염 된장은 8-12주 발효 후 효모수는 $10^{5} \mathrm{CFU} / \mathrm{g}$ 수준이었고, 겨자나 마늘 등 항균물질의 첨가로 $10^{3} \mathrm{CFU} / \mathrm{g}$ 으로 저하되었던 보고(Lee와 Kim, 2012)에 비하 여는 강황의 항균효과는 낮은 수준이었다. 호기성 세균은 대조구와 강황 $0.5-1 \%$ 첨가구에서 담금 초기에 비하여

Table 2. Changes in viable cell counts of microorganism of 'Doenjang' during fermentation

(Unit: $\log \mathrm{CFU} / \mathrm{g}$ )

\begin{tabular}{|c|c|c|c|c|c|c|}
\hline & \multirow{2}{*}{$\begin{array}{l}\text { Fermentation time } \\
\text { (weeks) }\end{array}$} & \multicolumn{5}{|c|}{ 'Doenjang'1) } \\
\hline & & Control & $\mathrm{T}-0.5$ & $\mathrm{~T}-1$ & $\mathrm{~T}-2$ & $\mathrm{~T}-3$ \\
\hline \multirow{4}{*}{ Yeast } & 0 & $4.30 \pm 0.21^{2)}$ & $4.32 \pm 0.27$ & $4.33 \pm 0.36$ & $4.33 \pm 0.30$ & $4.30 \pm 0.28$ \\
\hline & 4 & $6.17 \pm 0.16^{\mathrm{a}}$ & $6.19 \pm 0.18^{\mathrm{a}}$ & $6.18 \pm 0.20^{\mathrm{a}}$ & $5.98 \pm 0.16^{\mathrm{a}}$ & $5.61 \pm 0.18^{\mathrm{b}}$ \\
\hline & 8 & $6.37 \pm 0.34^{\mathrm{a}}$ & $5.80 \pm 0.27^{\mathrm{b}}$ & $5.65 \pm 0.29^{b}$ & $5.59 \pm 0.25^{\mathrm{b}}$ & $5.54 \pm 0.26^{\mathrm{b}}$ \\
\hline & 12 & $6.05 \pm 0.42$ & $5.77 \pm 0.41$ & $5.60 \pm 0.35$ & $5.57 \pm 0.38$ & $5.35 \pm 0.35$ \\
\hline \multirow{4}{*}{$\begin{array}{l}\text { Aerobic } \\
\text { bacteria }\end{array}$} & 0 & $7.94 \pm 0.37$ & $7.90 \pm 0.31$ & $7.79 \pm 0.36$ & $7.77 \pm 0.25$ & $7.73 \pm 0.21$ \\
\hline & 4 & $7.89 \pm 0.29$ & $7.86 \pm 0.36$ & $7.71 \pm 0.32$ & $7.46 \pm 0.27$ & $7.41 \pm 0.08$ \\
\hline & 8 & $8.03 \pm 0.44^{\mathrm{a}}$ & $8.02 \pm 0.35^{\mathrm{a}}$ & $7.89 \pm 0.47^{\mathrm{ab}}$ & $7.51 \pm 0.35^{\mathrm{ab}}$ & $7.16 \pm 0.45^{\mathrm{b}}$ \\
\hline & 12 & $7.58 \pm 0.46$ & $7.32 \pm 0.41$ & $7.28 \pm 0.43$ & $7.17 \pm 0.29$ & $7.10 \pm 0.44$ \\
\hline \multirow{4}{*}{$\begin{array}{l}\text { Anaerobic } \\
\text { bacteria }\end{array}$} & 0 & $7.32 \pm 0.55$ & $7.36 \pm 0.42$ & $7.38 \pm 0.31$ & $7.24 \pm 0.30$ & $7.20 \pm 0.19$ \\
\hline & 4 & $6.71 \pm 0.53$ & $6.72 \pm 0.41$ & $6.51 \pm 0.39$ & $6.28 \pm 0.41$ & $6.11 \pm 0.40$ \\
\hline & 8 & $7.12 \pm 0.41^{\mathrm{a}}$ & $6.84 \pm 0.46^{\mathrm{ab}}$ & $6.28 \pm 0.39^{b}$ & $6.11 \pm 0.48^{b}$ & $6.01 \pm 0.47^{\mathrm{b}}$ \\
\hline & 12 & $6.75 \pm 0.28^{\mathrm{a}}$ & $6.63 \pm 0.26^{\mathrm{a}}$ & $6.11 \pm 0.42^{\mathrm{ab}}$ & $5.81 \pm 0.46^{\mathrm{b}}$ & $5.78 \pm 0.30^{\mathrm{b}}$ \\
\hline
\end{tabular}

${ }^{1)}$ See the preparation of 'Doenjang' in Table 1.

${ }^{2)}$ Values are mean $\pm \mathrm{SD}(\mathrm{n}=3)$.

${ }^{3)}$ Means with different letters in the same row are significantly different by Duncan's multiple range test $(p<0.05)$. 
발효 8 주경에 근소하게 증가되었으나 그 이후에는 감소하 였고, 시험구간에는 대조구에 비하여 강황의 첨가비율이 증가할수록 호기성 세균수는 적은 수준이었다. 혐기성 세 균수도 발효 중에 감소하는 경향이었으며, 강황 첨가농도 가 높은 시험구에서 혐기성 세균수는 발효 후기에 대조구 에 비하여 유의적으로 $(\mathrm{p}<0.05)$ 감소되어 호기성 세균에 비하여 $1 \log \mathrm{CFU} / \mathrm{g}$ 이상 적었다. 한편, 강황 에탄올 추출물 은 tryptic soy agar 배지에서 식중독 세균의 최소저해농도 가 $0.1-0.3 \%$ 이었으며(Park 등, 2007), 김치 제조시 강황 $1 \%$ 첨가로 병원성 미생물의 성장이 2-3 $\log \mathrm{CFU} / \mathrm{g}$ 억제되 었던 Lee 등(1997)의 보고에 비하여 된장에서 세균 증식의 억제효과는 적었다. 이러한 경향은 된장성분이 강황의 미 생물 생육억제에 대해 보호 작용을 한 것으로 사료되었으 며, 감초나 겨자가 세균이나 효모에 대해 항균활성이 있으 나, 된장에 $0.7-0.8 \%$ 첨가하여도 거의 영향이 없었다고 Lim과 Song(2010)이 보고한 바 있다. 한편, Mok 등(2005)은 저식염 된장의 세균수는 $10^{6} \mathrm{CFU} / \mathrm{g}$, 효모수는 $10^{5} \mathrm{CFU} / \mathrm{g}$ 수준이었고, 발효 중 세균수는 6주 이후에 $1 \log \mathrm{CFU} / \mathrm{g}$ 정도 감소하나, 효모수는 발효초기에 약간 증가한 후 감소 하였다는 보고 및 Choi 등(2018)의 저염 된장에서 총 균수 는 발효 중 7.6- 8.0 $\log \mathrm{CFU} / \mathrm{g}$ 수준을 유지하였다고 보고 된 바 있어 본 실험 결과와 차이가 있었다.

\section{효소활성도}

된장은 발효과정에서 단백질과 전분이 효소에 의해 분 해되어 구수한 맛과 단맛을 내게 된다(Mok 등, 2005). 전 분분해효소 활성도의 발효 중의 변화는 Table 3 과 같이 $\alpha$-amylase와 $\beta$-amylase 모두 강황의 첨가비율이 증가할수록
담금 초기의 효소의 활성은 유의적으로 낮았는데 $(\mathrm{p}<0.05)$, 이는 강황의 첨가비율 증가분만큼 $k o j i$ 의 첨가비율을 줄였 던 담금 조건의 영향이었다. 발효 중의 변화는 8 주까지 효소활성은 저하되었으나, 12 주에는 조금 증가되는 경향 이었다. 시험구간에도 8 주 이후에는 효소 활성에 큰 차이 가 없어 발효 후기에는 koji 보다 발효 중에 생육하는 미생 물의 영향이 큰 것으로 사료되었다. 단백질분해효소의 활 성은 전분분해효소와는 달리 Table 4에서 보는 바와 같이 담금 초기에 비하여 산성 protease는 발효 8주, 중성 protease는 4주까지 활성도는 증가되었으며, 그 이후에는 감소하였고, 중성 protease는 12주경에는 조금 증가하는 경향이었다. 시험구간에는 산성 protease와 중성 protease 의 활성도 모두 amylase와는 달리 강황 첨가비율이 높은 시험구에서 발효 전 기간 동안 protease 활성이 낮았다. 이는 강황이 Table 2에서 보는 바와 같이 발효 중 미생물의 증식을 억제하여 protease 생성이 낮았던 것으로 사료되었 다. 따라서 된장 발효 중 효소활성도는 총 생균수보다 세균 의 종류에 따라 차이가 있는 것으로 사료되었다(Cha 등, 2017). 한편, 저식염 된장에서 효소 활성은 식염농도가 높 은 $12-14 \%$ 구가 8-10\%구에 비하여 발효 초기에 미생물 의 생육이 억제되어 amylase와 protease의 활성이 낮았다고 보고한 바 있다(Mok 등, 2005).

\section{색도}

소비자의 품질평가에 중요한 된장의 색도변화를 발효 기간 동안에 Hunter 색도계로 측정한 결과는 Table 5와 같다. 된장의 색도 중 밝기인 $\mathrm{L}$ 값과 황색도인 $\mathrm{b}$ 값은 발효 중에 저하되었으며, $\mathrm{L}$ 값이 $\mathrm{b}$ 값에 비하여 발효 초기에 저하

Table 3. Changes in amylase activity of 'Doenjang' during fermentation

(Unit: unit/g)

\begin{tabular}{|c|c|c|c|c|c|c|}
\hline \multirow{2}{*}{ Component } & \multirow{2}{*}{$\begin{array}{l}\text { Fermentation time } \\
\text { (weeks) }\end{array}$} & \multicolumn{5}{|c|}{ 'Doenjang,'1) } \\
\hline & & Control & $\mathrm{T}-0.5$ & $\mathrm{~T}-1$ & $\mathrm{~T}-2$ & $\mathrm{~T}-3$ \\
\hline \multirow{4}{*}{$\alpha$-Amylase } & 0 & $34.47 \pm 0.21^{\mathrm{a}}$ & $33.97 \pm 0.27^{\mathrm{a}}$ & $31.62 \pm 0.36^{\mathrm{ab}}$ & $28.72 \pm 0.30^{\mathrm{b}}$ & $27.04 \pm 0.28^{b}$ \\
\hline & 4 & $35.87 \pm 0.16$ & $34.53 \pm 0.19$ & $34.16 \pm 0.20$ & $34.40 \pm 0.16$ & $33.72 \pm 0.18$ \\
\hline & 8 & $26.36 \pm 0.34^{\mathrm{bc}}$ & $25.96 \pm 0.27^{\mathrm{c}}$ & $26.96 \pm 0.29^{\mathrm{ab}}$ & $27.02 \pm 0.25^{\mathrm{a}}$ & $27.10 \pm 0.25^{\mathrm{a}}$ \\
\hline & 12 & $32.51 \pm 0.42$ & $30.79 \pm 0.40$ & $30.26 \pm 0.35$ & $29.78 \pm 0.38$ & $28.26 \pm 0.36$ \\
\hline \multirow{4}{*}{$\begin{array}{c}\beta \text {-Amylase } \\
(\times 1,000)\end{array}$} & 0 & $4.26 \pm 0.12^{\mathrm{a}}$ & $4.01 \pm 0.15^{\mathrm{ab}}$ & $3.91 \pm 0.14^{\mathrm{bc}}$ & $3.74 \pm 0.14^{\mathrm{bc}}$ & $3.65 \pm 0.10^{\mathrm{c}}$ \\
\hline & 4 & $3.34 \pm 0.42$ & $3.28 \pm 0.51$ & $3.14 \pm 0.70$ & $3.07 \pm 0.65$ & $2.91 \pm 0.71$ \\
\hline & 8 & $3.05 \pm 0.15$ & $2.91 \pm 0.12$ & $2.92 \pm 0.28$ & $2.84 \pm 0.09$ & $2.73 \pm 0.22$ \\
\hline & 12 & $3.03 \pm 0.18$ & $3.10 \pm 0.37$ & $3.13 \pm 0.15$ & $3.32 \pm 0.26$ & $3.15 \pm 0.19$ \\
\hline
\end{tabular}

${ }^{1)}$ See the preparation of 'Doenjang' in Table 1 .

${ }^{2}$ ) Values are mean $\pm \mathrm{SD}(\mathrm{n}=3)$.

${ }^{3)}$ Means with different letters in the same row are significantly different by Duncan's multiple range test $(p<0.05)$. 
Table 4. Changes in protease activity of 'Doenjang' during fermentation

(Unit: unit/g)

\begin{tabular}{|c|c|c|c|c|c|c|}
\hline \multirow{2}{*}{ Component } & \multirow{2}{*}{$\begin{array}{l}\text { Fermentation time } \\
\text { (weeks) }\end{array}$} & \multicolumn{5}{|c|}{ 'Doenjang ${ }^{\prime 1)}$} \\
\hline & & Control & $\mathrm{T}-0.5$ & $\mathrm{~T}-1$ & $\mathrm{~T}-2$ & $\mathrm{~T}-3$ \\
\hline \multirow{4}{*}{$\begin{array}{l}\text { Acidic } \\
\text { protease }\end{array}$} & 0 & $3.17 \pm 0.53$ & $3.09 \pm 0.59$ & $3.03 \pm 0.83$ & $2.92 \pm 0.45$ & $2.81 \pm 0.55$ \\
\hline & 4 & $3.72 \pm 0.32$ & $4.03 \pm 0.52$ & $4.25 \pm 0.49$ & $3.86 \pm 0.51$ & $3.62 \pm 0.52$ \\
\hline & 8 & $5.12 \pm 0.48^{b}$ & $5.89 \pm 0.44^{\mathrm{a}}$ & $4.79 \pm 0.60^{\mathrm{b}}$ & $4.53 \pm 0.56^{\mathrm{b}}$ & $4.20 \pm 0.38^{b}$ \\
\hline & 12 & $4.89 \pm 0.67^{\mathrm{ab}}$ & $5.30 \pm 0.40^{\mathrm{a}}$ & $5.22 \pm 0.40^{\mathrm{a}}$ & $4.63 \pm 0.45^{\mathrm{ab}}$ & $4.15 \pm 0.71^{b}$ \\
\hline \multirow{4}{*}{$\begin{array}{l}\text { Neutral } \\
\text { protease }\end{array}$} & 0 & $4.58 \pm 0.55^{\mathrm{a}}$ & $4.54 \pm 0.74^{\mathrm{a}}$ & $4.25 \pm 0.47^{\mathrm{ab}}$ & $3.94 \pm 0.36^{\mathrm{bc}}$ & $3.44 \pm 0.29^{c}$ \\
\hline & 4 & $5.25 \pm 0.55$ & $5.28 \pm 0.31$ & $5.01 \pm 0.45$ & $4.81 \pm 0.44$ & $4.55 \pm 0.62$ \\
\hline & 8 & $4.19 \pm 0.19^{c}$ & $4.36 \pm 0.32^{\mathrm{bc}}$ & $4.58 \pm 0.41^{\mathrm{ab}}$ & $4.75 \pm 0.52^{\mathrm{a}}$ & $4.13 \pm 0.27^{\mathrm{c}}$ \\
\hline & 12 & $4.84 \pm 0.81^{\mathrm{b}}$ & $5.47 \pm 0.40^{\mathrm{a}}$ & $5.34 \pm 0.21^{\mathrm{a}}$ & $4.93 \pm 0.27^{\mathrm{ab}}$ & $4.50 \pm 0.47^{b}$ \\
\hline
\end{tabular}

${ }^{1)}$ See the preparation of 'Doenjang' in Table 1 .

${ }^{2}$ ) Values are mean $\pm \mathrm{SD}(\mathrm{n}=3)$.

${ }^{3)}$ Means with different letters in the same row are significantly different by Duncan's multiple range test $(\mathrm{p}<0.05)$.

Table 5. Changes in color values of 'Doenjang' during fermentation

\begin{tabular}{|c|c|c|c|c|c|c|}
\hline \multirow{2}{*}{$\begin{array}{l}\text { Hunter color } \\
\text { value }\end{array}$} & \multirow{2}{*}{$\begin{array}{l}\text { Fermentation time } \\
\text { (weeks) }\end{array}$} & \multicolumn{5}{|c|}{ 'Doenjang,'1) } \\
\hline & & Control & $\mathrm{T}-0.5$ & $\mathrm{~T}-1$ & $\mathrm{~T}-2$ & $\mathrm{~T}-3$ \\
\hline \multirow{4}{*}{$\mathrm{L}$} & 0 & $57.28 \pm 0.79^{\mathrm{a}}$ & $55.50 \pm 0.75^{\mathrm{b}}$ & $54.56 \pm 0.84^{b}$ & $52.84 \pm 0.85^{\mathrm{c}}$ & $49.58 \pm 0.67^{\mathrm{d}}$ \\
\hline & 4 & $48.54 \pm 0.37^{\mathrm{a}}$ & $47.56 \pm 0.95^{\mathrm{a}}$ & $46.82 \pm 1.52^{\mathrm{ab}}$ & $45.25 \pm 0.91^{\mathrm{b}}$ & $42.71 \pm 0.76^{\mathrm{c}}$ \\
\hline & 8 & $44.52 \pm 2.18^{\mathrm{a}}$ & $44.70 \pm 1.51^{\mathrm{a}}$ & $43.86 \pm 1.09^{\mathrm{a}}$ & $43.02 \pm 1.42^{\mathrm{ab}}$ & $41.00 \pm 0.38^{\mathrm{b}}$ \\
\hline & 12 & $43.66 \pm 0.91^{\mathrm{a}}$ & $43.37 \pm 0.60^{\mathrm{a}}$ & $42.99 \pm 0.43^{\mathrm{ab}}$ & $41.44 \pm 0.95^{\mathrm{bc}}$ & $40.83 \pm 1.45^{\mathrm{d}}$ \\
\hline \multirow{4}{*}{$\mathrm{a}$} & 0 & $2.54 \pm 0.64^{\mathrm{a}}$ & $1.28 \pm 0.55^{\mathrm{b}}$ & $0.74 \pm 0.62^{b}$ & $0.78 \pm 0.77^{\mathrm{b}}$ & $1.06 \pm 0.56^{\mathrm{b}}$ \\
\hline & 4 & $3.48 \pm 1.07^{\mathrm{a}}$ & $1.52 \pm 1.10^{\mathrm{b}}$ & $1.25 \pm 0.44^{\mathrm{b}}$ & $1.91 \pm 0.51^{\mathrm{b}}$ & $3.13 \pm 0.78^{\mathrm{ab}}$ \\
\hline & 8 & $4.21 \pm 0.99^{\mathrm{a}}$ & $2.61 \pm 0.97^{\mathrm{b}}$ & $2.49 \pm 0.66^{\mathrm{b}}$ & $2.85 \pm 0.82^{\mathrm{ab}}$ & $3.81 \pm 0.45^{\mathrm{ab}}$ \\
\hline & 12 & $5.53 \pm 0.68^{\mathrm{a}}$ & $4.80 \pm 0.96^{\mathrm{b}}$ & $3.43 \pm 0.49^{c}$ & $3.61 \pm 0.36^{\mathrm{bc}}$ & $4.63 \pm 0.34^{\mathrm{ab}}$ \\
\hline \multirow{4}{*}{$\mathrm{b}$} & 0 & $17.03 \pm 0.61^{\mathrm{c}}$ & $22.36 \pm 0.44^{\mathrm{b}}$ & $24.13 \pm 0.52^{\mathrm{a}}$ & $24.71 \pm 0.36^{\mathrm{a}}$ & $24.83 \pm 0.56^{\mathrm{a}}$ \\
\hline & 4 & $16.16 \pm 0.18^{d}$ & $20.02 \pm 0.47^{\mathrm{c}}$ & $21.71 \pm 0.67^{b}$ & $23.01 \pm 0.41^{\mathrm{a}}$ & $22.82 \pm 1.22^{\mathrm{b}}$ \\
\hline & 8 & $16.10 \pm 0.90^{\mathrm{c}}$ & $19.61 \pm 0.44^{\mathrm{b}}$ & $20.57 \pm 0.61^{\mathrm{ab}}$ & $21.57 \pm 0.45^{\mathrm{a}}$ & $21.18 \pm 0.47^{\mathrm{a}}$ \\
\hline & 12 & $16.21 \pm 0.43^{\mathrm{c}}$ & $18.66 \pm 0.50^{\mathrm{b}}$ & $19.45 \pm 0.39^{\mathrm{ab}}$ & $19.75 \pm 0.84^{\mathrm{a}}$ & $19.97 \pm 0.51^{\mathrm{a}}$ \\
\hline
\end{tabular}

${ }^{1)}$ See the preparation of 'Doenjang' in Table 1.

${ }^{2)}$ Values are mean \pm SD $(n=3)$.

${ }^{3)}$ Means with different letters in the same row are significantly different by Duncan's multiple range test $(\mathrm{p}<0.05)$.

가 심하였다. 적색도인 $\mathrm{a}$ 값은 이와는 달리 발효 중에 조금 증가되었다. 시험구간에는 강황의 첨가비율이 증가할수 록 $\mathrm{L}$ 값은 저하되었고, 황색도인 $\mathrm{b}$ 값은 유의적으로 $(\mathrm{p}<0.05)$ 증가하는 경향이었으나 적색도인 a값은 큰 차이가 없었다. 이러한 경향은 녹차(Jung과 Roh, 2004)의 첨가로 된장의 $\mathrm{L}$ 값과 $\mathrm{b}$ 값이 낮아졌고, 표고버섯을 첨가하면 $\mathrm{L}$ 값은 낮아
지나 a값이 높아 된장의 색도가 바람직하지 않았던 보고 (Choi 등, 2006)와는 달리 강황의 첨가는 된장의 발효 중 갈변에 의한 품질저하의 주요 원인이 되는 $\mathrm{b}$ 값의 저하를 억제할 수 있었다. 한편 된장에 감초 $(0.8 \%)$ 나 겨자 $(0.7 \%)$, 키토산 $(2.0 \%)$ 을 첨가하여 40 일간 발효시켜도 색도에는 거 의 영향이 없었고(Lim과 Song, 2010), 가정에서 제조된 
전통된장의 색도는 $\mathrm{L}$ 값과 $\mathrm{a}, \mathrm{b}$ 값이 평균 각각 $37.7,7.5$, 19.6 이었던 보고(Park 등, 2000)에 비하여 본 실험 된장이 밝고 적색도가 낮은 것으로 사료되었다.

변색도인 $\Delta \mathrm{E}$ 값(Table 6)은 발효가 진행되면서 변색이 진행되었고, 변색정도는 발효초기에 심하여 $\mathrm{Ku}$ 등(2009) 의 보고와 유사하였다. 시험구간에는 일정하지는 않지만 강황의 첨가로 변색도는 적었다. 한편, 된장의 갈색색소물 질은 파장 $487 \mathrm{~nm}$ 에서 최대흡광도를 보이며(Joo 등, 1992b) 발효 중에 Maillard 반응에 의한 갈변으로 명도가 저하되어 어둡고 색이 진해져 상품성이 떨어지나, 발효 중에 생성되는 oxalic acid 등 유기산이 갈변을 억제하였다 고 보고(Kwak과 Lim, 2003)되었다. 또한, 된장은 가열처리 하지 않으면 tyrosinase의 작용으로 L-dihydroxy phenyl alanine(L-DOPA)을 경유하는 효소적 갈변반응의 가능성 이 높았고(Kim 등, 1999), 갈변은 발효·숙성보다 유통저 장 기간 중에 일어난다고 보고한 바 있다(Kim, 1996).

\section{$\mathrm{pH}$ 와 적정산도, 산가}

된장 발효 중에 미생물에 의한 발효산물과 밀접한 관계 가 있는 $\mathrm{pH}$ 와 적정산도의 발효기간 중의 변화는 Fig. 1 과 같다. $\mathrm{pH}$ 는 발효가 진행되면서 4주까지는 저하되었으나, 그 이후에는 불규칙한 증감을 보였다. 시험구간에는 강황 첨가비율이 높은 시험구에서 $\mathrm{pH}$ 는 높았다. 적정산도는 $\mathrm{pH}$ 가 저하됨에 따라 증가하여 4주에 제일 높았고 그 이후 에는 불규칙한 증감을 보여 $\mathrm{pH}$ 변화와 유사한 경향이었다. 따라서 된장 담금시 강황의 첨가량이 증가하면 산도의 증가는 적었으며 이러한 경향은 Table 2에서 보는 바와 같이 강황 첨가량이 많은 시험구에서 효모와 세균수가 적었던데 기인하는 것으로 사료된다. 이러한 결과는 저식 염 된장에서 알코올을 첨가한 경우에 산도의 증가가 적었 고(Lee와 Kim, 2012), 고추씨 첨가량이 증가할수록 적정산 도가 완만하게 증가하였던 $\mathrm{Ku}$ 등(2009)의 보고와 유사하 였다. 또한, Lee와 Mok(2010)은 된장의 적정산도는 식염농 도가 낮으면 발효 중에 젖산균과 효모의 증식에 의해 생성 되는 유기산에 의해 발효 1 주에 급격히 증가하였다고 보고 한 바 있다.
(A)

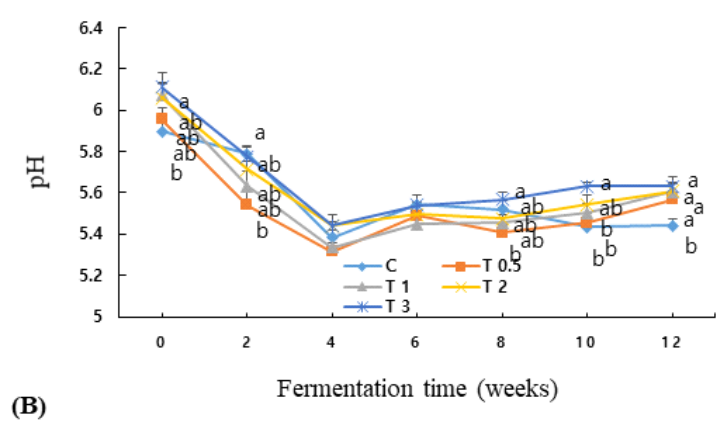

(B)

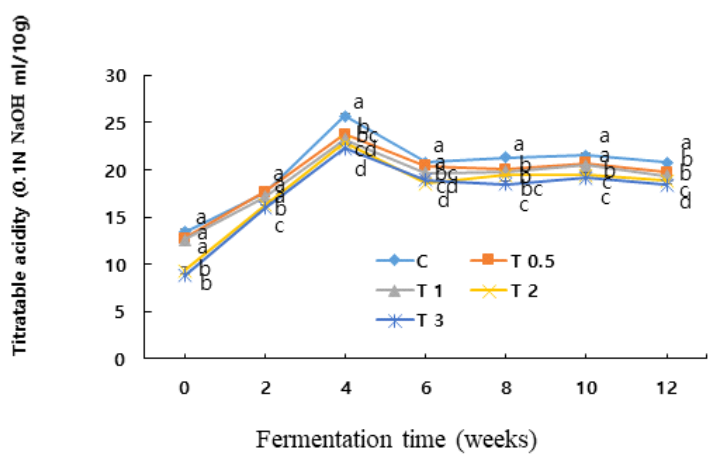

Fig. 1. Changes in pH and titratable acidity of 'Doenjang' during fermentation.

${ }^{1)}$ See the preparation of 'Doenjang' in Table $1 .{ }^{2)}$ Values are mean \pm SD $(n=3) .{ }^{3}$ Means with different letters above a bar are significantly different at $\mathrm{p}<0.05$.

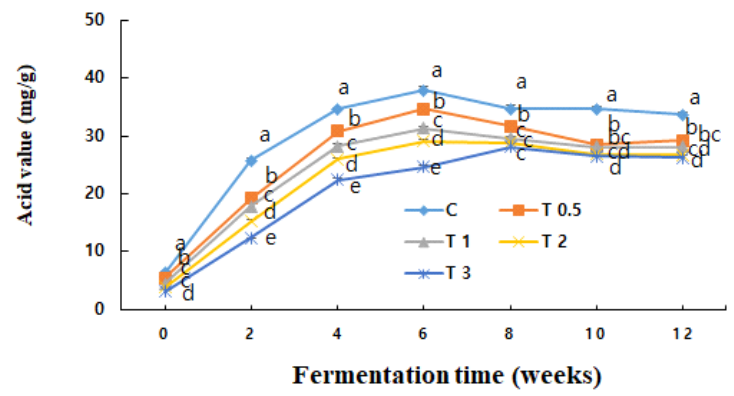

Fig. 2. Changes in acid values of 'Doenjang' during fermentation. ${ }^{1)}$ See the preparation of 'Doenjang' in Table $1 .{ }^{2)}$ Values are mean \pm SD $(n=3) .{ }^{3)}$ Means with different letters above a bar are significantly different at $\mathrm{p}<0.05$.

Table 6. Changes in total color difference of 'Doenjang' during fermentation

\begin{tabular}{cccccc}
\hline \multirow{2}{*}{$\begin{array}{c}\text { Fermentation time } \\
\text { (weeks) }\end{array}$} & Control & T-0.5 & T-1 & T-2 & T-3 \\
\cline { 2 - 5 } & 8.87 & 7.39 & 6.90 & 7.31 & 8.38 \\
4 & 10.65 & 9.95 & 10.64 & 10.64 & 9.42 \\
8 & 13.36 & 12.48 & 12.81 & 12.03 & 10.20 \\
\hline
\end{tabular}

\footnotetext{
${ }^{1)}$ See the preparation of 'Doenjang' in Table 1 .
} 
한편, 된장의 발효과정에서 지방이 분해되어 생성되는 유리지방산 함량을 측정한 산가는 Fig. 2와 같이 발효 2주 에 급격히 증가된 후 6-8주까지 증가하나 그 이후에는 서서히 감소하였다. 시험구간에는 강황의 첨가비율이 증 가할수록 산가는 유의적으로 $(\mathrm{p}<0.05)$ 낮았다. 이는 겨자 또는 마늘의 첨가구가 대조구보다 산가가 높았던 Lee와 $\operatorname{Kim}$ (2012)의 보고와 차이가 있었으며, 강황의 첨가로 된 장의 산가 증가를 효과적으로 억제할 수 있었다. 한편, $\mathrm{JoO}$ 등 (1992b)은 된장의 발효가 빠르면 산가 변화는 심하 고, 산가가 높으면 냄새가 불량한 원인이 될 수 있다고 보고하였다.

\section{산화환원전위와 수분활성도}

된장의 발효기간 동안 산화환원전위 $(\mathrm{ORP})$ 와 수분활성 도(Aw)의 변화는 Table 7과 같이 발효 4주 이후에 급격히 저하하여 8주에 - 454.4- $510.7 \mathrm{mV}$ 까지 감소하였으나 그 이후에는 완만히 저하되었다. 시험구간에는 발효 초기 인 4주까지는 강황 첨가비율이 증가하면 유의적으로 $(\mathrm{p}<0.05) \mathrm{ORP}$ 도 저하되었으나 그 이후에는 큰 차이가 없었 다. 한편 산화환원전위가 $-200 \mathrm{mV}$ 이하로 낮아지면 혐기 성 세균의 증식에 유리한 환경이 되어 호기성 세균의 증식 은 억제 된다고 보고(James, 2000)된 바 있어, 본 실험 된장 의 경우 산화환원전위는 발효 8주 이후에는 호기성 세균의 증식에 불리한 수준이었다. 이러한 결과는 고구마 된장의 경우 12 주 발효 후에도 ORP는 $-200 \mathrm{mV}$ 이상이었고(Cha 등, 2017), 에탄올이나 겨자, 마늘을 첨가한 된장에서 8 주 발효 후에 206.4-237.5 mV이었던 Lee와 $\operatorname{Kim}(2012)$ 의 보 고에 비하여 본 실험 된장의 $\mathrm{ORP}$ 는 낮아 담금 조건에
따라 차이가 심한 것으로 사료되었다.

수분활성도(Aw)는 발효 중에 수분함량이 증가하였음 에도 불구하고 Table 7과 같이 원료 성분들이 분해되어 저분자화 됨에 따라 용질의 몰분율이 증가하기 때문에 서서히 저하되었고(Kim, 1996), 시험구간에는 유의적인 차이는 없지만 강황 첨가구에서 $\mathrm{Aw}$ 는 높았다.

\section{환원당과 알코올}

된장의 단맛 성분으로 중요한 환원당의 발효기간 동안 의 변화는 Fig. 3과 같이 발효 4-6주까지 증가하였고 그 이후에는 불규칙하게 증감하다가 12 주에 다시 증가하였 다. 시험구간에는 강황의 첨가비율이 높은 시험구에서 환 원당 함량은 대조구에 비하여 낮았으며 $(\mathrm{p}<0.05)$, 전분분해 효소의 활성이 낮고 알코올의 생성이 높은 시험구에서 환원당은 낮은 경향이었다. 한편, 된장 발효 중의 환원당 함량은 각각 발효 10 일( $\operatorname{Kim}$ 등, 2000), 20일(Joo 등, 1992a), 40일(Lee 등, 2013), 10주(Lee와 Mok, 2010)에 높았다고 다르게 보고되어 $k o j i$ 종류와 배합비율 등 담금 조건에 따라 차이가 많은 것으로 사료되었다.

된장의 알코올(Fig. 3) 함량은 담금시 알코올을 $2 \%$ 첨가 하였으나 배합 과정에서 일부가 휘발되어 발효 초기에는 $2 \%$ 이하로 감소되었으나, 발효 2주 이후에는 발효에 의해 증가되었고, 증가 정도는 강황 첨가 비율이 높은 시험구에 서 발효 후기의 증가비율이 높은 경향이었다. 발효 과정에 서 알코올의 생성은 대조구보다 강황 첨가구에서 높아 Table 2의 효모수와는 달리 강황이 알코올 발효를 촉진한 것으로 사료되었다. 이러한 결과는 담금시 알코올을 $3 \%$ 첨가한 된장의 경우 발효후기에 효모수가 감소되어 알코

Table 7. Changes in oxidation-reduction potential and water activity of 'Doenjang' during fermentation

\begin{tabular}{|c|c|c|c|c|c|c|}
\hline \multirow{2}{*}{ Component } & \multirow{2}{*}{$\begin{array}{l}\text { Fermentation time } \\
\text { (weeks) }\end{array}$} & \multicolumn{5}{|c|}{ 'Doenjang,'1) } \\
\hline & & Control & $\mathrm{T}-0.5$ & $\mathrm{~T}-1$ & $\mathrm{~T}-2$ & $\mathrm{~T}-3$ \\
\hline \multirow{4}{*}{$\begin{array}{l}\text { Oxidation- } \\
\text { reduction } \\
\text { potential } \\
(-\mathrm{mV})\end{array}$} & 0 & $66.0 \pm 3.85^{\mathrm{c}}$ & $69.0 \pm 4.83^{\mathrm{bc}}$ & $76.0 \pm 5.60^{\mathrm{b}}$ & $76.4 \pm 4.17^{b}$ & $85.0 \pm 3.48^{\mathrm{a}}$ \\
\hline & 4 & $73.9 \pm 4.60^{\mathrm{b}}$ & $75.4 \pm 4.74^{\mathrm{b}}$ & $99.9 \pm 7.82^{b}$ & $103.5 \pm 9.15^{\mathrm{a}}$ & $105.0 \pm 6.62^{\mathrm{a}}$ \\
\hline & 8 & $508.7 \pm 79.39$ & $504.9 \pm 41.65$ & $510.7 \pm 58.68$ & $455.5 \pm 51.93$ & $454.4 \pm 41.88$ \\
\hline & 12 & $570.8 \pm 60.63$ & $562.3 \pm 48.33$ & $564.6 \pm 82.12$ & $562.8 \pm 29.72$ & $556.2 \pm 32.70$ \\
\hline \multirow{4}{*}{$\begin{array}{l}\text { Water } \\
\text { activity }\end{array}$} & 0 & $0.854 \pm 0.01$ & $0.858 \pm 0.01$ & $0.859 \pm 0.01$ & $0.860 \pm 0.00$ & $0.858 \pm 0.01$ \\
\hline & 4 & $0.831 \pm 0.00^{\mathrm{a}}$ & $0.835 \pm 0.01^{\mathrm{ab}}$ & $0.835 \pm 0.00^{\mathrm{ab}}$ & $0.840 \pm 0.00^{\mathrm{ab}}$ & $0.834 \pm 0.01^{\mathrm{b}}$ \\
\hline & 8 & $0.831 \pm 0.03$ & $0.835 \pm 0.00$ & $0.836 \pm 0.01$ & $0.837 \pm 0.01$ & $0.837 \pm 0.01$ \\
\hline & 12 & $0.828 \pm 0.01$ & $0.830 \pm 0.01$ & $0.829 \pm 0.00$ & $0.831 \pm 0.01$ & $0.831 \pm 0.00$ \\
\hline
\end{tabular}

${ }^{1)}$ See the preparation of 'Doenjang' in Table 1.

${ }^{2}$ ) Values are mean $\pm \mathrm{SD}(\mathrm{n}=3)$.

${ }^{3)}$ Means with different letters in the same row are significantly different by Duncan's multiple range test $(p<0.05)$. 
(A)

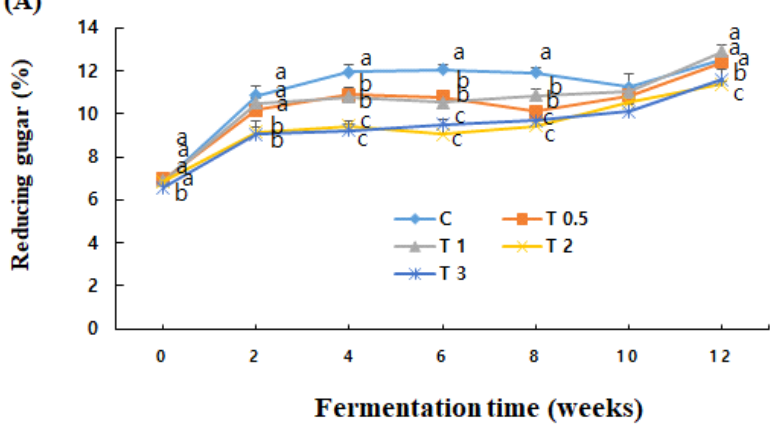

(B)

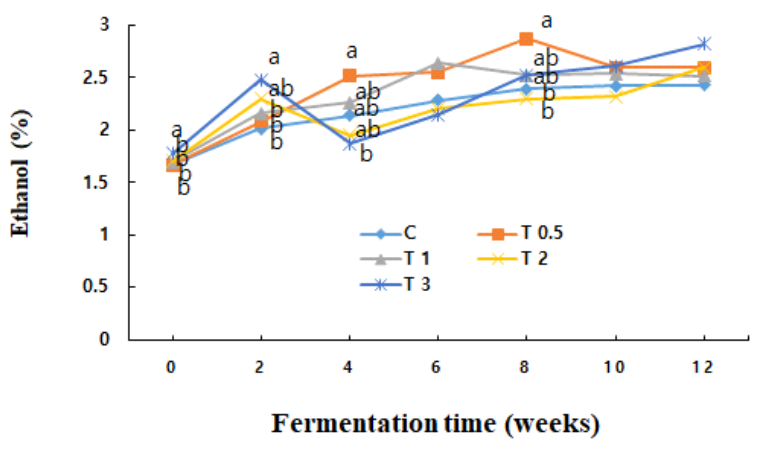

Fig. 3. Changes in reducing sugar and ethanol contents of 'Doenjang' during fermentation.

${ }^{1)}$ See the preparation of 'Doenjang' in Table $1 .{ }^{2)}$ Values are mean \pm SD $(\mathrm{n}=3) .{ }^{3}$ Means with different letters above a bar are significantly different at $\mathrm{p}<0.05$.

올 함량이 저하되었던 Cha 등(2017)의 보고와는 차이가 있었다. 한편, 된장의 알코올 생성은 40 일 발효 후 0.26 $3.42 \%$ 로 $k o j i$ 종류에 따라 차이가 심하였다고 보고된 바 있다(Joo 등, 1992a).

\section{질소성분}

된장은 발효 중에 단백질이 유리아미노산 형태로 분해 되어 구수한 맛을 내지만 지나치게 분해되면 암모니아성 질소의 증가로 바람직하지 않은 풍미가 된다. 아미노산성 질소는 Fig. 4와 같이 발효 중에 점점 증가하였다(Lee와 Mok, 2010). 2주 이후에는 전통식품의 표준규격(Ministry of Agriculture \& MForestry, 2007)인 $300 \mathrm{mg} \%$ 이상이 되었 으며, 밀된장은 70일 발효 후 $376.27-600.91 \mathrm{mg} \%$ 이었던 보고(Lee 등, 2013)보다 높은 편이었다. 시험구간에는 강황 의 첨가비율이 증가하면 발효 후기에 아미노산성 질소의 증가비율이 높은 경향이었다. 한편, 표고버섯을 메주의 $10 \%$ 비율로 첨가한 경우 아미노산성 질소는 대조구에 비 하여 2배 정도 높은 $401.4 \mathrm{mg} \%$ 이었다고 보고된 바 있다 (Choi 등, 2006).

된장의 바람직하지 않은 풍미와 연관될 수 있는 암모니 아성 질소는 Fig. 4와 같이 발효가 진행되면서 증가하여

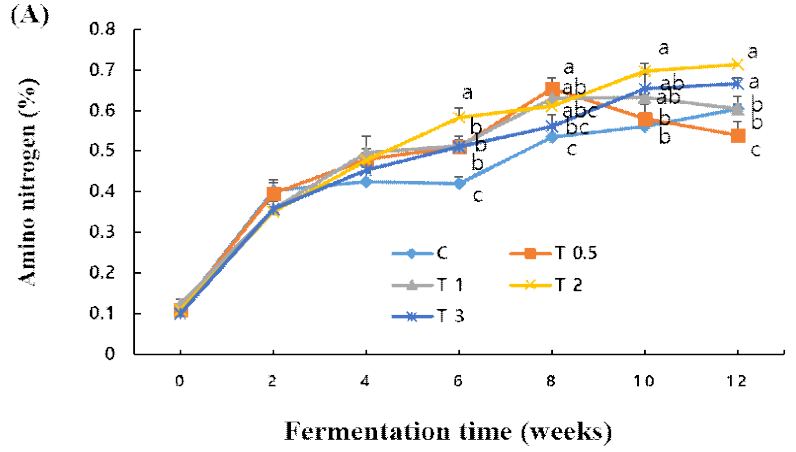

(B)

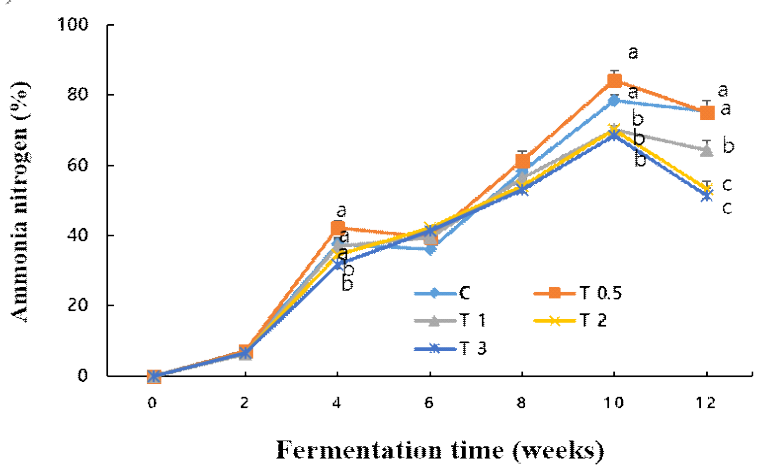

Fig. 4. Changes in amino and ammonia type nitrogen contents of 'Doenjang' during fermentation.

${ }^{1)}$ See the preparation of 'Doenjang' in Table $1 .{ }^{2)}$ Values are mean \pm SD $(n=3) .{ }^{3)}$ Means with different letters above a bar are significantly different at $\mathrm{p}<0.05$.

10 주에 최고에 달했으며, 그 이후에 감소하였다. 시험구간 에는 강황의 첨가 비율이 $1 \%$ 이상인 시험구에서 암모니아 성 질소의 비율이 낮았다 $(\mathrm{p}<0.05)$. 이는 Table 2 와 같이 강황 첨가비율이 높은 시험구에서 발효 중 효모와 세균수가 적 어 암모니아성 질소의 생성이 상대적으로 적었던 것으로 사료되었다. 이러한 경향은 Lee와 Mok(2010)의 식염 농도 가 낮을수록 휘발성 염기질소의 양이 발효 16 주까지 지속 적으로 증가하였던 보고와는 차이가 있었는데, 이는 강황 에 의한 항균작용의 영향인 것으로 사료되었다(Park 등, 2007). 이상의 결과들과 강황을 첨가한 고추장 $(\mathrm{Kim}, 2013)$ 에서 기호성을 고려하여 볼 때 된장 제조시 강황의 첨가비 율은 $0.5-1.0 \%$ 가 바람직한 것으로 사료되었다.

\section{요 약}

강황의 첨가비율을 달리하여 된장의 발효 중 이화학적 특성을 비교하였다. 된장의 효모수와 혐기성 세균수는 강황의 첨가비율이 증가할수록 발효 중에 감소하였고, $\alpha$-amylase와 산성 protease는 발효 후기에 낮은 활성을 보였 다. 강황의 첨가비율이 증가할수록 발효 중에 $\mathrm{L}$ 값은 낮아 지고 $\mathrm{b}$ 값은 증가하여 $(\mathrm{p}<0.05)$ 변색도 $(\Delta \mathrm{E})$ 는 적었다. 된장 
의 $\mathrm{pH}$ 는 발효가 진행되면서 4주까지는 저하되었으며, 강 황의 첨가비율이 증가하면 산도의 증가는 적었다. 산가 $(\mathrm{p}<0.05)$ 와 $\mathrm{ORP}$ 는 강황의 첨가비율이 증가할수록 낮았으 나 Aw는 높았다. 환원당은 발효 4-6주까지 증가되었으 나, 강황의 첨가비율이 높은 시험구에서 환원당 함량은 낮았고, 알코올은 강황 첨가비율이 높은 시험구에서 증가 비율이 높았다. 아미노산성 질소는 발효 중에 증가하였고, 강황의 첨가비율이 높은 시험구에서 높았으나, 암모니아 성 질소는 낮았다. 된장 제조시 강황의 첨가비율은 $0.5-$ $1.0 \%$ 가 바람직한 것으로 사료되었다.

\section{Conflict of interests}

The authors declare no potential conflict of interest.

\section{ORCID}

Dong-Han Kim https://orcid.org/0000-0003-0628-6145

\section{References}

Anson ML. The estimation of pepsin, trypsin, papain and cathepsin with hemoglobin. J Gen Physiol, 22, 79-89 (1938)

Cha SH, Park SR, Kim DH. Quality characteristics of Doenjang prepared with sweet potato. Korean J Food Preserv, 24, 221-229 (2017)

Choi BY, Gil NY, Mun JY, Yeo SH, Kim SY. Changes in the physicochemical characteristics of low-salted Doenjang by addition halophytes. Korean J Food Preserv, 25, 819-829 (2018)

Choi HS, Kang JE, Jeong ST, Kim CW, Kim MK. Changes observed in Doenjang containing fermented Rhus verniciflua extract during aging. Korean J Food Sci Technol, 47, 599-607 (2015)

Choi HY. Antimicrobial activity of ulgeum (Curcuma longa L.) extract and its microbiological and sensory characteristic effects in processed foods. Korean J Food Cookery Sci, 25, 350-356 (2009)

Choi SY, Sung NJ, Kim HJ. Physicochemical characteristies of traditional Doenjang with added Lentinus edodes. Korean J Food Cookery Sci, 22, 69-79 (2006)

Difco Laboratories. Difco Manual. 10th ed, Detroit, Michigan, USA, p 1064-1065 (1984)

Eum BW, Kwak BY, Kim SY, Shon DH, Lee KH. Enhancement of chitooligosaccharides in Doenjang (soybean paste) and Kanjang (soysauce) using Bacillus subtilis Koji and Rhizopus oryzae Koji. Korean J Food Sci Technol, 35, 291-296 (2003)

Fuwa HA. A new method for microdetermination of amylase activity by the use of amylose as the substrate. J Biochem, 41, 583-603 (1954)

Institute of Miso Technologists. Official Methods of Miso Analysis. Changpeungdang, Tokyo, Japan, p 1-34 (1968)

James MJ. Modern Food Microbiology. 6th ed, APAC, Nevada, USA, p 45-47 (2000)

Joo HK, Kim DH, Oh KT. Chemical composition changes in fermented Doenjang depend on Doenjang koji and its mixture. J Korean Agric Chem Soc, 35, 351-369 (1992a)

Joo HK, Oh KT, Kim DH. Effects of mixture of improved Meju, Korean traditional Meju and Natto on soybean paste fermentation. J Korean Agric Chem Soc, 35, 286-293 (1992b)

Jung BM, Roh SB. Physicochemical quality comparison of commercial Doenjang and traditional green tea Doenjang. J Korean Soc Food Sci Nutr, 33, 132-139 (2004)

Kang JR, Kim GM, Hwang CR, Cho KM, Hwang CE, Kim JH, Kim JS, Shin JH. Changes in quality characteristics of soybean paste Doenjang with addition of garlic during fermentation. Korean J Food Cook Sci, 30, 435-443 (2014)

Kim DH. Effects of turmeric (Curcuma longa L.) on the physicochemical characteristics of Kochujang during fermentation. J Appl Biol Chem, 56, 101-107 (2013)

Kim DY, Kwon DJ. Quality characteristics of Doenjang manufactured with soybean Koji. Korean J Food Preserv, 21, 434-441 (2014)

Kim EU, Rhyu MR. The chemical properties of Doenjang prepared by Monascus Koji. Korean J Food Sci Technol, 32, 1114-1121 (2000)

Kim JS, Choi SH, Lee SD, Lee KH, Oh MJ. Quality changes of sterilized soybean paste during its storage. J Korean Soc Food Sci Nutr, 28, 1069-1075 (1999)

Kim ND. Study on the browning and it's inhibition in soybean paste (Doenjang). Ph D Thesis, Konkok University, Seoul, Korea, p 1-116 (1996)

Kim SH, Kim SJ, Kim BH, Kang SG, Jung ST. Fermentation of Doenjang prepared with sea salts. Korean J Food Sci Technol, 32, 1365-1370 (2000)

$\mathrm{Ku} \mathrm{KH}$, Choi EJ, Park WS. Quality characteristics of Doenjang added with red pepper (Capsicum annuum L.) seed. J Korean Soc Food Sci Nutr, 38, 1587-1594 (2009) 
Kwak EJ, Lim SI. Effect of addition time of antibrowning agents on browning and fermentation characteristics in Doenjang. J Korean Soc Food Sci Nutr, 32, 495-500 (2003)

Lee GR, Ko YJ, Kim EJ, Kim IH, Shim KH, Kim YG, Ryu $\mathrm{CH}$. Ouality characteristics of wheat Doenjang according to mixing ratio of Meju. Korean J Food Preserv, 20, 191-198 (2013)

Lee JY, Mok CK. Changes in physicochemical properties of law salt soybean paste (Doenjang) during fermentation. Food Eng Prog, 14, 153-158 (2010)

Lee S, Kim DH. Changes in physicochemical properties of low-salt Doenjang during fermentation. Korean J Food Sci Technol, 44, 592-599 (2012)

Lee SH, Choi WJ, Lim YS, Kim SH. Antimicrobial effect of ethanol extract from Curcuma aromatica S. J Food Sci and Technol, 9, 161-165 (1997)

Lim SI, Song SM. Fermentation properties of low-salted Doenjang supplemented with licorice, mustard, and chitosan. Korean J Food Sci Technol, 42, 323-328 (2010)

Martin EP. Use of acid, rose bengal, and streptomycin in the plate method for estimating soil fungi. Soil Sci, 69, 215-232 (1950)
Miller GL. Use of dinitrosalicylic acid reagent for determination of reducing sugar. Anal Chem, 31, 426-431 (1959)

Ministry of Agriculture and Forestry. Traditional Food Standard Specifications. Seoul, Korea, p 99 (2007)

Mok CK, Song KT, Lee JY, Park YS, Lim SB. Changes in microorganisms and enzyme activity of law salt soybean paste (Doenjang) during fermentation. Food Eng Prog, 9, 112-117 (2005)

Okada Y, Yamaguchi N, Yoshii H. Effect of sodium chloride on bitterness of desalted soybean miso. Nippon Shokuhin Kagaku Kogaku Kaishi, 44, 259-264 (1997)

Park KN, Jeong EJ, Lee SH. Antimicrobial activity of turmeric (Curcuma aromatica Salab.) extracts against various pathogens and spoilage bacteria isolated from tofu. Korean J Food Preserv, 14, 207-212 (2007)

Park SK, Seo KI, Shon MY, Moon JS, Lee YH. Quality characteristics of home-made Doenjang, a traditional Korean soybean paste. Korean J Soc Food Sci, 16, 121-127 (2000)

Thomas YD, Lulvwes WJ, Kraft AA. A convenient surface plate method for bacteriological examination of poultry. J Food Sci, 46, 1951-1952 (1981) 